Rok XV (2020) | 1 (29)| S. 215-225

https://doi.org/10.12797/LV.15.2020.29.14

Rafał Młyński (1)

Jagiellonian University, Cracow

rafal.mlynski@uj.edu.pl

\title{
INTERACTIONIST INTERPRETATION OF THE COMMUNICATIVE COMPETENCE OF A BILINGUAL CHILD SUSPECTED OF DYSLEXIA
}

Słowa klucze: dwujęzyczność, dysleksja, symboliczny interakcjonizm, kompetencja komunikacyjna Keywords: bilingualism, dyslexia, symbolic interactionism, communication competence

\section{Symbolic interactionism in sociolinguistic and theory of logopedics}

Herbert Blumer's theory of symbolic interactionism in Polish linguistics was reflected in sociolinguistics, which were made possible due to the publications of Stanisław Grabias. The researcher referred to Blumer's conclusions and presented his own reflections mainly in the monograph Język w zachowaniach społecznych (Grabias 1997) and the article Język, poznanie, interakcja (Grabias 2007).

According to Grabias, interaction is based on giving meaning to human behavior and the determinant of its ordering is:

1) understanding behavior as a sign - human behavior is a carrier of meaning and can take the form of indices or intentional signs that are beyond the will of the sender, by means of which it expresses its intentions and anticipates the reactions of the sender,

2) creating behaviors - dependent on the process of sender's and receiver's socialization and awareness, allowing for conscious control of responses to stimuli, 
3) receiving behaviors - possible due to reaching the transmitter's psychological states, determining the coherence of his behavior and identifying or rejecting the received human attitude,

4) the situation - the repetitive pattern of senders and recipients with their social roles and mutually intertwined intentions implemented in time and space,

5) intention - action being a reaction, caused and organized by human, active and goal-oriented (Grabias 1997: 245-257).

When defining the interaction, he stated that it is "a system of two adjacent processes: processes of giving meaning to human behavior and the process of adapting their own behavior to the behavior of members of a given social group" (Grabias 2007: 358).

It is possible due to the fact that language has a greater potential for meaning - it not only organizes learning about reality, but also conditions the transfer of knowledge about it to other participants in the social group and intellectualizes epistemic processes (ibid.: 355-356, see also Michalik 2013a: 19).

The basic functions of linguistic interaction are cognitive and communicative, and the necessary conditions for their occurrence are:

a) the condition of the identity of knowledge about oneself and the world - the closer the interlocutor's experiences are, the more effective are the interactions in which they enter,

b) the condition of the structural identity of knowledge about oneself and the world - interaction participants who use the same ethnic language have a similarly structured knowledge about the world, because language is a tool providing intersubjective categories of cognition of reality,

c) the condition of the identity of the structure and knowledge resources about the subject of interaction - the more subjective the knowledge of the interlocutors is the more effective the interaction,

d) the condition of identity of transmission patterns and ways of their implementation - the more interactive behavior is carried out according to the stereotypical scenario, the more effective it is (Grabias 2007: 358-359).

\section{Interactionist theory of logopedics}

Grabias has signaled the possibility of using interactionism in logopedics while at the same time redefining understanding of logopedics as a science. Interactional threads in logopedics are related to the position that it is a science "about the biological conditions of language and language behavior" (Grabias 2010/2011: 17-18).

The subject of the researcher's and speech therapist's assessment is cognitive competence, language competence, communication competence and efficiency in its implementation. These competencies are examined in relation to physical hearing and 
phonemic awarness, a properly functioning central nervous system and memory, the effects of the peripheral nervous system and the muscular and bone organ system of speech. Competences and skills result from the biological capabilities of the individual and their shape is expressed in the person's social life, because language organizes the social sphere of the human being and the interactions an individual undertakes. Lack or dysfunction of language behavior can place the individual outside the mainstream of social life (ibid.: 18-19). The above competences are realized in human speech. Considering the framework of interactionism, it is necessary to change the definition, reaching the conclusion that "speech is a system of activities that a human performs with the participation of language, learning about the world and transmitting knowledge about themselves and the world to other participants in social life" (ibid.: 22).

The new understanding of speech conditioned Grabias' proposition of a diagnostic model in which there are interactive skills, i.e. motorics, pronunciation, language, conceptual structures, implementation of dialogue, implementation of narrative statements and transmission in the form of intentions (ibid.: 23-31). Interactionist analysis of linguistic disorders was also presented the examples of aphasia (see Panasiuk 2013a, 2013b), autism spectrum disorders (see Szwajda 2014) and cerebral palsy with oligophasia (see Michalik 2013a, 2013b, 2013c).

\section{Bilingualism and dyslexia as elements of the interactionist interpretation of communicative competence}

Poland's entry into the structures of the European Union and the ever-increasing scale of economic, social and political migration ${ }^{1}$ are factors that determined the emergence of new research fields, including in applied linguistics. One of them is bilingualism, especially in childhood. The increase in the number of children for whom the Polish language is not the only communication tool, currently puts before the speech - language pathology researchers and practitioners the urgent task of creating tools and standards for diagnostic and therapeutic procedures, thus, taking into account the conditions of bilingualism in Poland (Czaplewska 2018: 279). Accepting the position of Mirosław Michalik, that logopedics is a science characterized by openness and cognitive dynamism, deciding upon the constant determination of its field adequate to the times (Michalik 2015: 33-34), it is reasonable to include the problem of communication competence disorders in bilingualism in the scope of modern speech-language therapy. Understanding linguistics used as interactional

1 In 2014, 12.3 thousand people arrived in Poland to settle permanently, including 5.2 thousand at the age of $0-19$. In this group, the most numerous were children aged $0-4(72.4 \%)$. The children who came to Poland, were both foreign and Polish diaspora (Czaplewska 2018: 262). 
science allows for the interpretation of linguistic behaviors of disordered bilingual persons in the spirit of symbolic interactionism.

\section{Proposal for a theoretical framework}

In the proposed theoretical construct, dyslexia should be understood as a:

low level of efficiency associated with the use of writing, when reading is significantly below expected based on IQ in the presence of other symptoms - lack of coordination, confusion of the left and right, weak sequential efficiency - what characterized by dyslexia as a neurological syndrome (Stein 2001: 12).

Dyslexia is an endogenous provocation disorder resulting from an abnormal structure and function of the cerebellum (Finch, Nicolson, Fawcett 2002; Rae et al. 2002: 1285-1292; Eckert et al. 2003: 482-494) or the brain (Habib 2000: 2376; Høien, Lundberg 2000: 124; Ramus 2004: 2). The world's literature also presents the etiological genetic theory (Paracchini, Scerri, Monaco 2007: 63; Scerri, Schulte-Körne 2010: 189; Peterson, Pennington 2012: 2003) and the hormonal theory (McManus, Bryden 1991: 237; Gayán Guardiola 2001: 15). Following the contemporary, holistic understanding of bilingualism (Ng, Wiggleworth 2007; Grosjean 2008, 2012) should describe rather than categorize and define a bilingual person. A useful tool is the profile of the bilingual unit proposed by François Grosjean. It includes information on: a) type of language used, b) language domains, c) language biography, d) language skills, e) activation of language systems during communications and cultural identity (Grosjean 2012: 18).

Dyslexia and bilingualism have become the subject of joint, though scarce, research. One of the most important findings is transfer across languages, which involves the transfer of reading quality in $\mathrm{L}_{1}$ and L2. Similar reading errors were seen in Chinese and English speakers, as well as Kannada (one of the Dravidian language) and English (Chung, Ho 2010; Joshi, Padakannaya, Nishanimath 2010). Another aspect that was noticed when comparing dyslexia symptoms in different languages is the importance of transparency of the written subcode to the spoken one. It has been established that dyslexics using a transparent alphabetic system (e.g. in Italian) have lower intensity of dyslexic errors than readers in opaque languages (e.g. in English or French; see Johansson 2006).

The study of communicative competence under the conditions of dyslexia and bilingualism requires the determination of the mutual relationship between these two factors: the biological etiology of reading and writing disorders is primary in relation to the bilingualism produced in the course of interpersonal language contacts. The analysis of linguistic material will therefore refer to the monolingual, interactionist skills of the individual, struggling above all with biological limitations and 
secondly conditioned by the influence of the second language. The collected data will be related to the themes of the theory of symbolic interactionism, already used in speech-language therapy (Michalik 2013a, 2013b). An important aspect of interaction research in terms of bilingualism is the proposal of Jacek Warchala, which is an interpretation of the general assumptions of interactionist language communication research: 1. The process of exchange in communication is, in fact, the action of specific individuals, which presupposes individualistic treatment of both the process of creating and receiving a message. 2. Communicating is a conscious process and the message itself should be considered in teleological categories such as convincing and determining (reconciling) common sense, as creating rather than recreating this sense. 3 . The communication process takes place through the interaction of participants who activate identifying at the character level and interactively negotiate it, creating sense. This assumption transforms the concept of the sign towards a play between meaning and sense, through which communication appears not so much as an unidirectional flow of meanings, but rather a two-way co-creation of meanings. 4. Participants of the communication act are focused on co-creating the text as a whole (postulate of holism), which is revealed above all in colloquial dialogue (Warchala 2003: 79-80).

\section{Research methodology}

The selection of the qualitative strategy of the following study is the result of identical application in the analysis of the Polish language in four cases of bilingual children with dyslexia. This study was the subject of the author's doctoral thesis entitled Język polski dzieci dyslektycznych w sytuacji ich bilingwizmu. Analiza przypadków (Młyński 2016a) ${ }^{2}$. The work itself can be treated as a starting point for extended, scientific reflections of this type.

This approach gains in importance because it allows deep analysis of the observed phenomenon (Pilch, Bauman 2001: 268). Because of it, it is possible to focus on a narrow problem and determine its specificity, especially if it has not been widely described so far in the literature (Wilczyńska, Michońska-Stadnik 2010: 154; Banaszkiewicz 2015: 379). The technique used to acquire data is the analysis of the product, or written expression. Due to the nature of the collected research material, it will be interpreted as part of symbolism and the complexity of communication and interactive meaning.

2 The dissertation is available in the library of the Center for Polish Language and Culture in the World of the Jagiellonian University. 


\section{Presentation of the research results}

Profile M. is a bilingual person in Grosjean's model (determined at the time of the study; during this research he was 10 years old):

a) parallel use of Spanish and Polish - the first of them was the heritage language, the second was the language of a school education; his parents were Argentines; he had brother T., 2 years younger; M. was learning in primary school in Cracow with Polish peers;

b) domains of the Spanish language were located in the family home - conversations with parents, their friends and relatives in Argentina through telephone; domains of the Polish language were located at school - conversations with teachers, peers and in the family home - conversations with brother T.;

c) M. had been in Poland since the age of 1.5 ; he began education in Polish at 7 years of age; he went to Argentina twice a year, where he used mainly Spanish but Polish too (with his brother as parents reported); diagnosed with specific difficulties in reading and writing (dyslexia) in Polish ${ }^{3}$, but not in Spanish because of the lack of Spanish literacy assessment and a Spanish speech-language pathologist in Cracow. The lack of diagnosis of the level of reading and writing in Spanish and the comparison of bilingual data did not allow a definitive and reliable diagnosis of dyslexia. Despite the lack of reliable differential diagnosis, however, there were premises on the basis of which M.'s dyslexia could be suspected, i.e. difficulties in drawing letters (dysgraphia), organization of the text, its delimitation and memory. In this respect, a significant fact was that M. participated in Polish-language diagnostic tests of the correctness of reading and writing (rewriting, writing from memory and by ear), which were subjected to comparative analysis with language data from his brother $\mathrm{T}$. Both boys began studying at the Polish school at the same time, however M. was worse than his younger brother in reading studies and writing. While reading the text aloud, reading from memory and by ear, M. presented many deficits in the sequential order of the language material, which manifested themselves in syntagmatic errors (elisions, metathesis), while his brother did not record such operations (Młyński 2016b: 125-128). The neurological etiology of disorders of linear processing of language units in dyslexia and reports of the transfer accross languages of dyslexia symptoms in bilingual persons suggest that $\mathrm{M}$. would present specific difficulties in reading and writing also in Spanish. In view of this, it is reasonable to use the term "suspected of dyslexia" about M.;

d) in Spanish he understood and spoke at a high level, could read and write simple texts; in Polish he understood and spoke at a high level; reading and writing was limited (mainly due to probable dyslexia) but allowed basic functioning in the Polish education system;

3 The diagnosis was at the psychological-pedagogical clinic using a battery of Polish tests. 
e) observed language phenomena in speaking and writing indicated the frequent use of a bilingual communication model with interferences;

f) monocultural identification (Argentinian). Collected data ${ }^{4}$ :

$[1]^{5} \mathrm{~W}$ Argentynie jemy gril o 12 [2] gril jemy u dziatkach [3] o 12 zawsze z mojm tatą i ja dajemy na całom siłe radio i przychodzą do domu dziatka lub do bapci nasza rodzina i jemy grill który na Argentynie nazywa się Asado [4] wargentynie w asado jemy kiłbaski miensa i tesz jemy świnie która dajemy do asado [5] dasie do asado włorzyć wszystko [6] kiedy jestem u dziatkach to się bawie z kuzynami w chowanego w berka a berek po chiszpańsku to się nazywa la mancia [7] dorośli robią gril w nowym roku jest terż gril i szczelamy petardami o 12 [8] W Argentynie najepszym jedzienym na świecie to jest mienso i terz gril [9] mama, bapcia, pra bapcia, ciocia oni robią obiat do grila [10] mamy bardzo długi stu z dzewa

Phot. 1. M.'s written product (source: own collection)

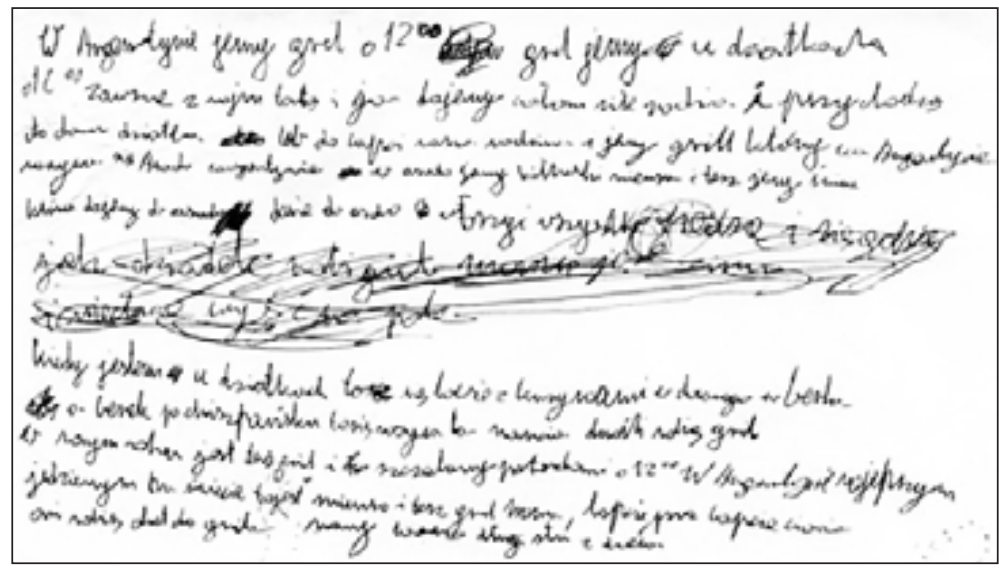

Interpretation of the collected data:

Symbolicity and complexity of communication: in the interaction theory the symbol is a communication tool that has a complex character, because it includes a phonological subsystem, morphological, lexical, syntactic, stylistic, para-language components falling within the prosody range, paraprozodic components and nonverbal elements (Michalik 2013b: 124). In the above written product one can observe two kinds of language operations - those that could result from dyslexia and contact of the two languages.

4 I give the child's text in the original. The subject of the work was: How do you spend your free time in Argentina?

5 I mark sentences with Arabic numerals because the boy's work is characterized by a clear lack of delimitation of the text. 
Dyslexia should be assigned errors in coding the phonological subsystem in graphic terms in the sequential order, e.g. a letter deleted /el - |kiłbaski/, |l/ - Inajepszym/,/1/ - /stu/ and a replacement /i/ - /jedzienym/.

Other symptoms of dyslexia in M. may be the very indistinct nature of the writing (dysgraphy resulting from weak motor skills) and delimitation of the text (see Phot. 1).

The influence of the Spanish language on Polish can be attributed to difficulties with keeping Polish grammar rules - ljemy u dziatkach/, ljestem u dziatkach/, erroneous use of prepositions / $\mathrm{na}$ /, which depending on the context in Spanish /en/ may also accept the meaning $/ w /$, lexical mistake - ljemy świnie/ instead of /mięso wieprzowe/ or /wieprzowinal, because Spanish /cerdo/ means /wieprzowinal or /świnial, addition in a pronoun $/ \mathrm{ja} /$, fulfilling the function of amplifying the termination Iz mojm tata $i \mathrm{ja} /$.

Analyzing the impairments within communication competence in M., we have to observe a signal of his metalinguistic competence in the semantic range ${ }^{6}-$ ljemy gril który na Argentynie nazywa się Asado/, /berek po chiszpańsku to się nazywa la mancial.

The above short presentation of the symptoms of dyslexia and inter-lingual contact allows for some conclusions. Polish productions may contain syntagmatic errors as well as grammatical or lexical lacks. Considering the biological etiology of dyslexia, it can be expected that syntagmatic errors could also occur within the Spanish language itself. The observed language operations have implications for the boy's educational support, which should have a dual nature. Probable dyslexia would require speech-language therapy, training oriented on sequential processing of language material and teaching Polish as a second language, by which the Argentine would improve in Polish grammar and lexical subsystems in Polish.

Giving meanings: the text presented above can be treated as an example of an interactionist negotiation of meaning, the purpose of which is to determine the meaning intended by the sender and recognized by the recipient (Panasiuk 2013a: 31). The I grill/ noun, defined in Polish as a "social event related to baking dishes on a metal grate under which the fire is burning", has been negotiated (WSJP PAN).

In the utterance of M. /gril/, substituted by the noun /asado/ is a diverse, meat meal - ljemy gril/, /gril jemy u dziatkach/, I w asado jemy kiłbaski miensa i tesz jemy świnie która dajemy do asado/, /dasie do asado włorzyć wszystko/. The meal described by the boy also constitutes an element of family gatherings - Iprzychodza do domu dziatka lub do bapci nasza rodzina ijemy grill, /dorośli robia gril w nowym roku/. In the iberoamerican culture /asado/ means not only a meat meal, but also a meeting

6 Also defined as metalinguistic awareness, it is the ability to become aware of the importance of three language components: morphological, syntactic and semantic (Gindrich 2001: 117). 
of the family who eats, talks and plays together (see Casalins 2010). The prominence by M. of the first meaning of nouns /grill/ i /asado/ could have been to emphasize the advantages of such a meal, which is expressed also in a sentence / W Argentynie najepszym jedzienym na świecie to jest mienso i terz gril/. The message can be interpreted as an attempt to convey to the Polish-speaking recipient the specificity and uniqueness of the Argentinian meat delicacy, which is associated with the boy's family. The effectiveness of the presented interactionist act was dependent on the recipient's understanding of meaning /asado/, which in the child's assumption could have been achieved by using and co-negotiating the sense of noun $/ \mathrm{grill} /$.

\section{Summary}

This research field definitely deserves an in-depth analysis, taking into account the fact that the competence of bilingual persons is an individual and dynamic property in which the current needs of the communicating person are reflected (Garcia 2009: 29). The moment of negotiating and giving meaning to a boy in need of transferring Spanish-language reality into the rules of the Polish language system, is particularly noteworthy at the same time willing to convey a message to the Polish-speaking recipient. The complicating element is dyslexia, which prevents the full use of the written communication channel. Despite these factors, M.'s communication goal should be considered realized because the recipient understood the meaning of his speech.

\section{References}

BANASZKiewicz A., 2015, Studium przypadku (case study) jako metoda badań jakościowych, [in:] S. Milewski, K. Kaczorowska-Bray (eds), Metodologia badań logopedycznych $z$ perspektywy teorii i praktyki, Gdańsk, pp. 364-38o.

Casalins E., 2010, El libro del asado argentino, Buenos Aires.

Chung K.K.H., Ho C.S.H., 2010, Second Language Learning Difficulties in Chinese Children With Dyslexia: What Are the Reading-Related Cognitive Skills That Contribute to English and Chinese Word Reading?, "Journal of Learning Disabilities" 43(3), pp. 195-211, [on-line:] https://doi.org/10.1177\%2Foo22219409345018.

Czaplewska E., 2018, Rola logopedii we współczesnych społeczeństwach wielokulturowych, [in:] eadem (ed.), Logopedia międzykulturowa, Gdańsk, pp. 261-281.

Eckert M., Leonard C.M., Richards T.L., Alyuard E.M., Thomson J., Berningrt V.W., 2003, Anatomical Correlates of Dyslexia: Frontal and Cerebellar Findings, "Brain" 126(2), pp. 482-494, [on-line:] https://doi.org/10.1093/brain/awgo26.

Finch A., Nicolson R.I., FAWCETT A.J., 2002, Evidence for a Neuroanatomical Difference Within the Olivo-Cerebellar Pathway of Adults with Dyslexia, "Cortex" 38(4), pp. 529-539, [on-line:] https://doi.org/10.1016/Soo10-9452(08)70021-2. 
Garcia O., 2009, Bilingual Education in 21st Century. A Global Perspective, Oxford.

Gayán Guardiola J., 2001, The Evolution of Research on Dyslexia, "Anuario de Psicologia" 32(1), pp. 3-30.

GINDRICH P., 2001, Znaczenie systemu językowego, świadomości fonologicznej oraz metajęzykowej w badaniach nad geneza dysleksji, "Audiofonologia” 19, pp. 175-181.

Grabias S., 1997, Język w zachowaniach społecznych, Lublin.

Grabias S., 2007, Język, poznanie, interakcja, [in:] T. Woźniak, A. Domagała (eds), Język, interakcja, zaburzenia mowy. Metodologia badań, Lublin, pp. 355-377.

Grabias S., 2010/2011, Logopedia - nauka o biologicznych uwarunkowaniach języka i zachowaniach językowych, "Logopedia" 39/40, pp. 9-34.

Grosjean F., 2008, Studying Bilinguals, Oxford.

Grosjean F., 2012, Bilingual. Life and Reality, Cambridge.

Навів M., 2000, The Neurological Basis of Developmental Dyslexia: An Overview and Working Hypothesis, "Brain" 123(12), pp. 2373-2399, [on-line:] https://doi.org/10.1093/ brain/123.12.2373.

Høien T., Lundberg I., 200o, Dyslexia. From Theory to Intervention, Dordrecht.

Johansson B.B., 2006, Cultural and Linguistic Influence on Brain Organization for Language and Possible Consequences for Dyslexia: A Review, "Annals of Dyslexia" 56(1), pp. 13-50, [on-line:] https://doi.org/10.1007/s11881-006-0002-6.

Joshi R., Padakannaya, P., Nishanimath S.S., 2010, Dyslexia and Hyperlexia in Bilinguals, "Dyslexia" 16(2), pp. 99-118, [on-line:] https://doi.org/10.1002/dys.402.

McManus I.C., Bryden M.P., 1991, Geschwind's Theory of Cerebral Lateralization: Developing a Formal, Causal Model, "Psychological Bulletin" 110(2), pp. 237-253, [on-line:] https://doi.org/10.1037/0033-2909.110.2.237.

Michalıк M., 2013a, Teoria logopedii jako interakcja, [in:] M. Michalik, A. Siudak, H. Pawłowska-Jaroń (eds), Interakcyjne uwarunkowania rozwoju i zaburzeń mowy, Kraków, pp. 13-31.

Michalıк M., 2013b, Porażona interakcja. Koncepcja interakcji językowej jako głos w sprawie dyzartrii o podłożu mózgowego porażenia dziecięcego, [in:] M. Michalik, A. Siudak, H. Pawłowska-Jaroń (eds), Interakcyjne uwarunkowania rozwoju i zaburzeń mowy, Kraków, pp. 107-138.

MiснацIK M., 2013c, Interakcyjna perspektywa opisu zaburzeń komunikacji (na przykładzie pacjentów z mózgowym porażeniem dziecięcym i oligofazja), [in:] J. Panasiuk, T. Woźniak (eds), Język, człowiek, społeczeństwo. Księga jubileuszowa dedykowana Profesorowi Stanisławowi Grabiasowi, Lublin, pp. 619-631.

Michalıк M., 2015, Transdycyplinarność logopedii - między metodologiczna koniecznościa a teoretyczna utopia, [in:] S. Milewski, K. Kaczorowska-Bray (eds), Metodologia badań logopedycznych z perspektywy teorii i praktyki, Gdańsk, pp. 32-46.

MŁYŃsKi R., 2016a, Język polski dzieci dyslektycznych w sytuacji ich bilingwizmu. Analiza przypadków, unpublished doctoral dissertation, Faculty of Polish Studies, Jagiellonian University.

MŁYŃski R., 2016b, Lingwistyczne objawy dysleksji i dwujęzyczności. Próba analizy różnicowej zachowań językowych, [in:] R. Dębski, W.T. Miodunka (eds), Bilingwizm polsko-obcy dziś. Od teorii i metodologii badań do studiów przypadków, Kraków, pp. 119-131.

Ng B.C., Wigglesworth G., 2007, Bilingualism. An Advanced Resource Book, London.

PANASIUK J., 2013a, Afazja a interakcja. TEKST - metaTEKST - konTEKST, Lublin. 
PANASIUK J., 2013b, Tekst - metatekst - kontekst w perspektywie teorii interakcji. Implikacje metodologiczne, [in:] M. Karwatowska, A. Siwiec (eds), Komunikacja - tradycja i innowacje, Chełm, pp. 30-58.

Paracchini S., Scerri T., Monaco A., 2007, The Genetic Lexicon of Dyslexia, "Annual Review of Genomics and Humans Genetics” 8, pp. 57-79, [on-line:] https://doi.org/10.1146/ annurev.genom.8.080706.092312.

Peterson R., Pennington B., 2012, Developmental Dyslexia, “Lancet” 379(9830), pp. 1997-2007, [on-line:] https://doi.org/10.1016/So140-6736(12)60198-6.

Pilch T., Bauman T., 2001, Zasady badań pedagogicznych. Strategie ilościowe i jakościowe, chap. 6 ed. by A. Radźko, $2^{\text {nd }}$ ed., revised and extended, Warszawa.

RAE C. ET AL., 2002, Cerebellar Morphology in Developmental Dyslexia, "Neuropsychologia" 40(8), pp. 1285-1292, [on-line:] https://doi.org/10.1016/soo28-3932(o1)oo216-o.

Ramus F., 2004, Neurobiology of Dyslexia: A Reinterpretation of the Data, "Trends in Neurosciences" 27(12), pp. 720-726, [on-line:] https://doi.org/10.1016/j.tins.2004.10.004.

Scerri T., Schulte-Körne G., 2010, Genetics of Developmental Dyslexia, "European Child and Adolescent Psychiatry" 19(3), pp. 179-197, [on-line:] https://doi.org/10.1007/ soo787-009-0o81-0.

Stein J., 2001, The Magnocellular Theory of Developmental Dyslexia, "Dyslexia” 7(1), pp. 12-36, [on-line:] https://doi.org/10.1002/dys.186.

Szwajda U., 2014, O mówieniu bez komunikowania, czyli dyskurs i interakcja w autyzmie. Charakterystyka trudności, "Socjolingwistyka” XXVIII, pp. 93-107.

Warchala J., 2003, Kategoria potoczności w języku, Katowice.

Wielki słownik języka polskiego PAN. Geneza, koncepcja, zasady opracowania, praca zbiorowa, red. P. Żmigrodzki, M. Bańko, B. Batko-Tokarz, J. Bobrowski, A. Czelakowska, M. Grochowski, R. Przybylska, J. Waniakowa, K. Węgrzynek, Kraków 2018.

Wilczyńska W., Michońska-Stadnik A., 2010, Metodologia badań w glottodydaktyce. Wprowadzenie, Kraków.

WSJP PAN: P. Żmigrodzki (ed.), Wielki słownik języka polskiego PAN, [on-line:] wsjp.pl.

\section{Interactionist Interpretation of the Communicative Competence of a Bilingual Child Suspected of Dyslexia \\ Summary}

The aim of this study was to include child bilingualism and dyslexia in the framework of the theory of symbolic interactionism. The reason for the presented issue is the necessity to extend the research of bilingualism in Poland and its connotations, which are associated with the phenomenon of migration of members of societies. The test method used a case study. Bilingualism and dyslexia were referred to the communication competence of a bilingual boy, interpreted according to selected threads of the interactionist theory. 